\title{
Communication Model of Indonesian Student Organizations in China through the Indonesian Movement Helps
}

\author{
Dani Fadillah ${ }^{1}$, Uspal Jandevi ${ }^{2}$ \\ ${ }^{1}$ University of Ahmad Dahlan \\ Jl. Kapas No.9, Semaki, Umbulharjo, Yogyakarta, Daerah Istimewa Yogyakarta 55166, Indonesia \\ ${ }^{1,2}$ Nanjing Normal University \\ No. 1 Wenyuan Road, Nanjing 210023, China \\ Email: dani.fadillah@comm.uad.ac.id ${ }^{1 *}$;30185309@stu.njnu.edu.cn² \\ *Corresponding author
}

\begin{abstract}
The Indonesian Movement Helps organization located in China helps Indonesian students while studying in China, but some Indonesian students initially had difficulty communicating with the organization. Many Indonesian students are victims of irresponsible scholarship agents. This research aims to analyze the communication barriers of the Indonesian Movement Helps organization in helping Indonesian students in China. This research method is qualitatively descriptive with data collection techniques through observation and in-depth interviews. Data analysis techniques using SWOT analysis. The results found a communication model of Indonesian student organizations in China through the internalization of the climate and culture of the word of mouth communication in Indonesian Movement Helps. The substance of this research is the communication model of Indonesian student organizations in China through the internalization of climate and culture of the word of mouth communication that can be applied to student organizations in other countries. Keywords: Communication model of Indonesian in China; Culture of the Word of Mouth Communication; Indonesian Movement Helps; Organization
\end{abstract}

\begin{abstract}
Abstrak
Organisasi Indonesian Movement Helps yang berada di China membantu mahasiswa Indonesia selama belajar di China, namun beberapa mahasiswa Indonesia awalnya kesulitan dalam berkomunikasi dengan organisasi tersebut. Banyak mahasiswa Indonesia menjadi korban agen beasiswa yang tidak bertanggungjawab. Penelitian ini bertujuan untuk menganalisis hambatan komunikasi organisasi Indonesian Movement Helps dalam membantu mahasiswa Indonesia di China. Metode penelitian ini deskriptif kualitatif dengan teknik pengumpulan data melalui observasi dan wawancara mendalam. Teknik analisis data menggunakan SWOT analisis. Hasil penelitian menemukan model komunikasi organisasi mahasiswa Indonesia di China melalui internalisasi iklim dan budaya komunikasi dari mulut ke mulut pada Indonesian Movement Helps. Substansi penelitian ini berupa model komunikasi organisasi mahasiswa Indonesia di China melalui internalisasi iklim dan budaya komunikasi dari mulut ke mulut yang dapat diterapkan pada organisasi mahasiswa di negara lain. Kata kunci: Model Komunikasi Mahasiswa Indonesia di China; Budaya Komunikasi dari Mulut ke Mulut; Organisasi Indonesian Movement Helps; Organisasi
\end{abstract}

\section{Introduction}

After more than two decades ago it is estimated that China will emerge as one of the superpower countries (Fadillah, 2020) right now the country has truly become one of the centers of world power starting from the political to the economic aspect (Fadillah \& Kumajaya, 2017), besides the two points, people from various countries across the world also felt drawn to come to China to study, including those from Indonesia (Fadillah et al., 2020). The Chinese government also provides a very attractive scholarship offer. It prevails to anyone who wishes to continue their studies in China from the level of diploma to doctoral level. This policy stimulates the wave of foreign students who come to continue their studies within China. It has been growing every year.

Based on the researcher's observations, the Chinese policy provides one of the very interesting scholarships, it emerges scholarship agents who offer scholarship application filing services for Indonesian students who want to study within China. Based on the 
researcher's observation as well, from several scholarship agents who take advantage of this situation, several agents have succeeded in helping Indonesian students. However, many unscrupulous agents are only looking for a mere profit. The agents raise their hands after the Indonesian students have arrived within China.

As writing this article, the researcher had been discussing the issues with some Indonesian students particularly those who became the victims of the unaccountable scholarship agents. They said that before their departure to China, they were promised to get various facilities during their study in China. However, after their arrival in China, the professed facilities were not available. In fact, they had to pay in a great number if they were required to get proper facilities during their study in China. Moreover, they had paid a great deal of money to the agents. Moreover, there were other Indonesian students who succeeded to get maximal facilities from the Chinese government during their study in the country. In this matter, they definitely did not get them from the agents. It is a horrible condition because there are a great number of Indonesian students who become victims of the scholarship agents.

Furthermore, three factors cause them to become victims of the scholarship agent. First, they immediately receive all the scholarship agent's information and quickly give the amount of money they ask for without double-checking first. Second, the inactive Indonesian student organizations in China provide scholarship information to prospective students in Indonesia. Third, scholarship agents often infiltrate when Indonesian student organizations conduct scholarship outreach in their respective regions in Indonesia.

For those who become the victims of the scholarship agents during their study in China, in some ways, their life is harder. Besides focusing on their study as their obligation as a student, they have to work or carry out business activities. If not, they cannot survive in China. For the students who take work, it is very risky. China's laws and regulations firmly forbid those who hold student visas to work. If caught, some sanctions will wait for them from fines, jail to deportation.

Based on these cases, the Indonesian Movement Helps was established to give assistance and facilitate Indonesia students as the victims of the unscrupulous scholarship agents. The organization has started its activities since 2016 after some Indonesian students studying in Nanjing were uncomfortable due to the financial difficulties among their fellow students. Within China, itself there is the Indonesian Students Association in China but its work programs did not cover this issue. Based on the information that the researcher had had before the Indonesia Movement Helps was founded there remained some organizers of the association who did not know that some of their fellow students, unfortunately, became the victims of the unscrupulous scholarship agents. Meanwhile, other Indonesian citizens were caring but unorganized. There was no organization that was able to facilitate the care of the issues. To answer the anxiety, the organization of The Indonesian Movement Helps was founded.

In general, The Indonesian Movement Helps has goals to arouse the sense of care particularly among Indonesian citizens who live in China, cooperate, and collaborate. It must beremembered that despite The Indonesian Movement Helps is honestly able to accept donations for Indonesian students who need it but it is not a fundraising organization. The tension arouses in caring for other fellow Indonesian students who are in such a condition in China. It not only contributes to the funding but also discharges potential talents and skills of Indonesian citizens being not developed yet in China. Because The Indonesian Movement Helps is an organization, this research is also inseparable from a series of theories discussing organization; from the theoretical examination of an organization, we can understand some important points to explain in this study. 
Previously there had been research on SWOT analysis of internal communication strategy of BPJS branch office, Yogyakarta city (Graita \& Hastasari, 2018), this research confirms that SWOT analysis in organization communication is a strength for an organization's success. Corporate communication that has been analyzed can help human resources more leverage in carrying out tasks, work better. there is also a study entitled SWOT analysis to determine strategic positions in the university of Lancang Kuning Pekanbaru (Nofrizal, 2018), in this study, the author emphasized that organizations need to apply SWOT analysis to survive, compete, and excel when paired with various other institutions.

In general, The Indonesian Movement Helps has goals to arouse the sense of care particularly among Indonesian citizens who live in China, cooperate, and collaborate. It must be remembered that despite The Indonesian Movement Helps is honestly able to accept donations for Indonesian students who need it but it is not a fundraising organization. The tension arouses in caring for other fellow Indonesian students who are in such a condition in China. It not only contributes to the funding but also discharges the potential talents and skills of Indonesian citizens is not developed yet in China. The Indonesian Movement Helps is an organization, this research is also inseparable from a series of theories discussing organization; from the theoretical examination of an organization, we can understand some important points to explain in this study.

So far, the presence of The Indonesian Movement Helps has succeeded to accompany some Indonesian students who need our help. Finally, they are graduated and can live independently. The presence of The Indonesian Movement Helps will be a speck of hope for Indonesian students who vigorously want to reach their dream of accomplishing their studies in China despite they have to encounter the unexpected condition since some unscrupulous scholarship agents almost destroy their studies.

\section{The Organization Theory}

An organization is a collection of people. The existence of limitations in humans encourages to form organizations. Human abilities, both physically and intellectually, are limited, while the activities that must be done are always increasing, helping people to build organizations. So in every organization will consist of a group of people. People in the organization interact and work together to achieve the goals set by the organization (Manullang, 2013). In interacting in the organization, the people in it must be arranged in a predetermined scheme so that the rhythm of the movement produced in the interaction can advance the organization and can accelerate the organization's process of achieving its goals; the system is called organization management (Manullang, 2009).

Furthermore, the organizing scheme is more than just a formality but has been transformed into a culture firmly held by whoever is part of the organization. Organization culture is a form of beliefs, values, ways that can be learned to cope with and live in an organization; corporate culture tends to be manifested by the organization's members (West \& Turner, 2007). This phenomenon makes Karl Weick formulate that certain events (such as organizations) are created by what is being discussed or communication activities (Hatch, 2013).

Weick's theory uses communication as a basis for human organization and provides a rationale for understanding how humans organize. The organization is not an arrangement formed by position and role, but by communication activities. Organizational activity directly refers to establishing certain levels of words. Weick takes the form of uncertainty and ambiguity, integrity: Organizations try to transform ambiguous information to a specific degree that is workable and adaptable (Hatch, 2013). 
Weick's organizing theory is also significant in communication because, according to his discussion, it is the basis of human organizing and provides a rational understanding of how to organize people. The organization does not make a structure of positions and roles but communication activities. The interactions formed by the organization consist of actions, statements, or behaviors from individuals. Organization activities fill the function of reducing information uncertainty. According to Weick, all information from the environment is ambiguous at several levels. The process of removing obscurity is a process that develops with three parts: enactment, selection, and retention (Mary, 2018).

The organization itself is an ongoing process of communication. When humans carry out daily interactions, the activities they do create organizations. All behavior is linked because someone's behavior depends on the behavior of others. The interactions that make up an organization consist of an individual's actions, statements, or practice, what is important is how other people respond to those actions. Weick believes that all organization activities are multiple interactions (Hatch \& Cunliffe, 2006).

All information from the environment, according to Weick, is equivocal or ambiguous to some degree, and organization activities are designed to reduce the lack of certainty. The organization is an evolutionary process with three parts: Enactment, selection, and retention. Enactment is the definition of a situation or registers ambiguous information from outside. The selection process on organization members accepts the information as relevant and rejects other information. The third process is retention, something that will be maintained for later use (Mary, 2018).

Humans communicate to reduce uncertainty, they undergo a series of behavior cycles or habits that allow the group to explain things. In a behavioral period, members' actions are governed by assembly rules that guide the choice of practices used to complete the process that is being carried out (making, selecting, or storing). These rules are the criteria by which organization members decide what to do to reduce gloom or uncertainty. The essential elements of the Weick's model, namely environment, obscurity, creation, selection, storage, choice points, behavior cycles, and rules of action, all contribute to the reduction of camouflage. These elements work together in a system; each of these elements is competitively related (Mary, 2018).

\section{Organization Culture}

Organizational culture is an opportunity to build Human Resources through the aspect of changing attitudes and behavior, which are expected to be able to adapt to ongoing and future challenges. Organizational culture is an invisible social force that can move people in an organization to carry out work activities. The management of the organization has an essential role in the communication pattern, which will become the official model of organization communication (Purnomo, 2010), the purpose of an organization's communication is to create a harmoniousrelationshipbetween the management to increase the motivation to build an organization and solve problems together (Supratman, 2018).

Unconsciously everyone in the organization learns the prevailing culture in the organization. For example, if we have a new person in an organization, he tries to determine what is right, what is wrong, what is allowed, what cannot be done, and what is not. It can be done. So the organization culture socializes and internalizes the members of the organization.

An influential organization culture supports company goals; on the other hand, a weak organization culture or contrary to company goals will hinder the company. In a company with influential organization culture, shared values are deeply understood, embraced, and fought for by most members of the organization. A strong and positive culture greatly influences the behavior and performance effectiveness of an organization or institution. 
Organizational culture affects the behavior of members or individuals and groups within an organization. The organization culture that exists within the organization can be healthy, and it can be weak. Culture is said to be stable if these shared values, attitudes, and beliefs are understood and adhered to firmly and with a high commitment to creating a sense of togetherness. On the other hand, weak organization culture is reflected in the lack of commitment of members to the values, beliefs, and shared attitudes that are usually carried out or agreed upon (Budiman, 2015).

Organizational culture has a vital role in managing an organization or institution. In general, every organization leader must be familiar with and apply modern management principles, such as the use of structural approaches, systems, strategies, and others, although some are still managed traditionally. However, many organizational leaders ignore the importance of organization culture, even though organization culture can be used as a management tool to achieve efficiency, effectiveness, productivity, and work ethics.

Based on background and library studies, this research aims to analyze the communication barriers of the Indonesian Movement Helps organization in helping Indonesian students in China.

\section{Research Methods}

This paper includes the research results and discussion of qualitative descriptive research. In this matter, the researcher collected various information concerning the research subject and object (Maxwell \& Reybold, 2015). The subject of this research is the Indonesian Movement Helps organization located in Nanjing City. At the same time, the object of this research is how the SWOT analysis they do in their organization to be able to improve further its performance in assisting the people of Indonesia in Nanjing city, especially students.
As gathering the information, the researcher conducted the in-depth interviews with the Indonesian Movement Helps organization starting from the founder of the organization, the Board of Trustees, the Chairperson, the Secretary, and other management ranks if it was required. The research location was in Nanjing City, China. It was the center of all the activities of The Indonesian Movement Help organization and the place where it was first founded and began its work programs. It analyzed the data with the SWOT analysis logic to get the research results.

The SWOT analysis is a technique used to do a self-reading and so, it will find out what things the organization should consider in detail. Therefore, in certain times the organization can take the right measures to be best able to survive and grow. The failure of the organization to do a self-reading can cause stagnation, undevelopment, and disappearance (Schooley, 2019). Theoretically, the SWOT analysis is believed to be able to facilitate an organization to do a self-reading; with the method, those from the internal and external organization which potentially develop or threaten the organization can be detected immediately (Gurel, 2017).

As long as we know that the acronym of SWOT is Strengths, Weaknesses, Opportunities, and Threats. The strengths have the meaning that what things from within the organization can become a strong capital for the organization to keep moving, something internal within the organization can be the quality of human resources or the financial conditions that the organization currently has. The weaknesses mean that what things from within the organization can inhibit the flow of the organization. Finding weaknesses is the same as finding cancer cells. The cells must be removed immediately before they get bigger and bigger. Finally, these have the worst effect on the organization. The opportunities mean that anything from outside the organization has the potential to advance and support the organization's performance, the presence of 
networks, and the organization partners or similar ones. These can be a kind of opportunity for an organization. Finally, the threats are anything that comes from outside the organization but has the potential to inhibit lane of the organization, the appearance of competitors or those can limit the organization's activities which can be included in this case (Abubakar \& Bello, 2013).

The performance of an organization is shown a difference in whether it conducts a SWOT analysis or not. If an organization carries out the SWOT analysis, it will show more promising performance, be capable of showing and taking opportunities with a good effect on the organization and be capable of avoiding and discarding everything with the potential to harm such an organization (Phadermrod et al., 2019).

Finally, it is believed that as an organization conducts the SWOT analysis, it has very high stability, and enthusiastically gives birth to the latest breakthroughs in each of its work programs. It is because the organization already has the maturity in executing every opportunity and knowing what things should be approached and what things should be avoided (Osita et al., 2014).

\section{Results of Research and Discussion}

Based on the interviews and discussions with the researcher, the information was obtained that The Indonesian Movement Helps was firstly founded to answer the anxiety of Indonesian citizens whose sadness on the unfortunate condition of some Indonesian citizens in China. They experienced difficulties economically because they did not get facilities like some other Indonesian students. While some Indonesian students in China got the facilities of free tuition and lodging fees as well as allowance totaling thousands of yuan from the Chinese government each month, some of the other students in China did not get. The unscrupulous scholarship agents had deceived them. Sometimes they had to pay their educational and other unexpected needs.
It could occur. The scholarship agents who facilitated them to go to China did not tell in detail and thoroughly the scholarship they would receive. As long as they knew that they had received a scholarship and were able to leave China immediately. However, they arrived in China, it was unexpected that there were many expenses they had to pay. For children who come from a wealthy family, this may not be a big problem. However, it is a different story if they come from a mediocre family. They have to sacrifice a lot of things to survive their study in China. From the information that the researcher got, there were some Indonesian students who held in hunger for days. They did it because they could not buy any food.

In such circumstances, they still had the spirit to continue their studies in China. Therefore The Indonesian Movement Helps is founded to facilitate the care of several other Indonesian students who want to help their fellow Indonesian students in unfortunate conditions.

So far it stands, The Indonesian Movement Help has successfully carried out the organization's goals well. It is proven that several fostered students of the organization have graduated from college and can live independently. In the Webinar conducted by Indonesian students across countries, the presence of The Indonesian Movement Helps in China has inspired the establishment of similar organizations in several countries where there are many Indonesian students who study here. In fact, there are many Indonesian students in other countries who experience similar disadvantages to those in China.

From the results of SWOT analysis, there are a number of things to be the concern of The Indonesian Movement Helps and so, it can further improve the quality and behavior of the organization;

Strengths: every activist who has joined the management of The Indonesian Movement Help has the same dream as the vision and 
mission of The Indonesian Movement Help organization. Before joining the management of The Indonesian Movement Help them have been selected at first that The Indonesian Movement Helps is a non-profit organization. There is no material benefit that they will get when working in The Indonesian Movement Helps. What they will get is their satisfied feeling because they have their shared happiness with their fellow students from their homeland. "Jadi saya itu merasa tersentuh karena saat sampai di China banyak anakanak Indonesia yang hidupnya prihatin, padahal saya percaya dimasa depan nanti merekallah yang akan memimpin bangsa kita, maka saya pelan-pelan mengajak para pelajar Indonesia lainnya yang memiliki kelebihan (ekonomi) dan berkenan untuk menyisihkan waktu luangnya bersamasama dengan sukarela membantu pelajar Indonesia lainnya yang membutuhkan". (Agus Supriyadi, PNS Jawa Barat, PhD student of Nanjing Normal University, The Founder of The Indonesian Movement Help. Interview on August 2, 2019 - Nanjing City) It was proven when they were active in The Indonesian Movement Helps they had never complained due to no payment and others. Based on the observations and information that the researcher had received they feel proud because they had become part of The Indonesian Movement Helps as the representation of the concern of the nation's children for their fellow citizens.

Besides they have a united breath of struggle with the organization, the activists of The Indonesian Movement Helps also have useful abilities to support the organization's socialization and performance. For example, they have capable of creating audio-visual production and writing. The Indonesian Movement Helps has had a lot of audio-visual productions to promote the organization. All the works are socialized on social media facilities such as WeChat, Instagram, YouTube, and so on in Indonesia and China. Publication media belonging to the Indonesia Movement Helps can be seen in table 1.

The organization of The Indonesian Movement Helps also has launched a book entitled "Lectures With The Costs of IDR0.0", a paper from The Indonesian Movement Helps marketed both domestically and abroad, as a means of sharing inspiration and socialization for all fellow citizens. The profits from the book are totally entered into the organization's budget to help Indonesian students with the aforementioned case.

It is definitely impossible that various audiovisual works and writings can be realized if there is no support from the personal abilities of the management. In short, The Indonesian Movement Helps has capital in a kind of soft skills and hard skills of its activists. Moreover, there are also members of The Indonesian Movement Helps with bookkeeping skills and so, the organization has an auditable financial record. Therefore, if at any time anyone asks about where the funds from the donors, The Indonesian Movement Helps can give a convincing answer.

The activists with various abilities can collaborate with each other as well and so, it will create a cool organization climate and far from conflict. If there is a conflict in an organization, it is not constructive. If each

Table 1. Media Publication of The Indonesian Movement Helps

\begin{tabular}{ll}
\hline \multicolumn{1}{c}{ Media } & URL \\
\hline YouTube & https://www.youtube.com/channel/UCbjAruBHfzMOm2bJtHdv1WQ \\
Instagram & https://www.instagram.com/gerakanindonesiamembantu/?hl=id \\
Facebook & https://www.facebook.com/gerakanindonesiamembantu \\
\hline
\end{tabular}

Source: Author's personal research (2019) 


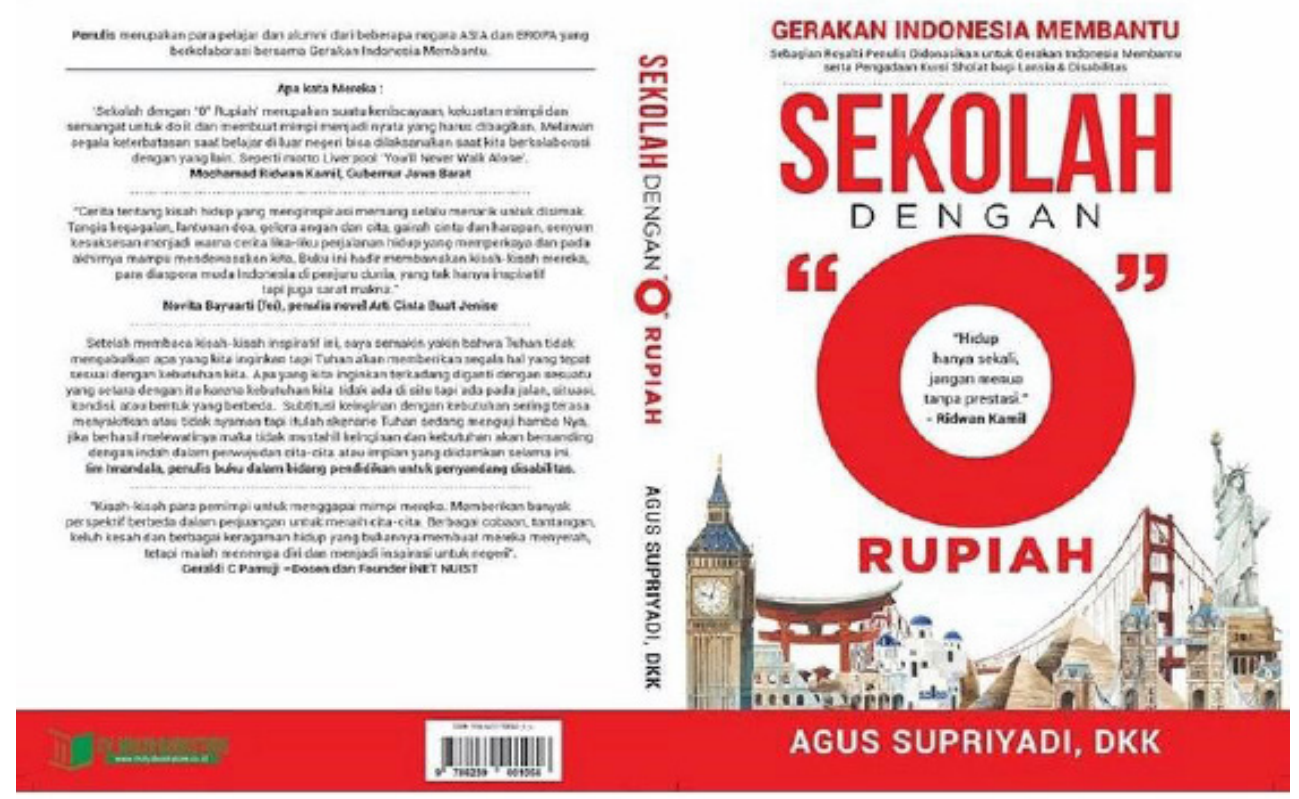

Figure 1. The book of "Sekolah dengan 0 Rupiah"

Source: Agus Supriyadi, Founder of Indonesia Movement Helps, (2019)

individual organizer is able to play his or her roles well, it makes The Indonesian Movement Helps as an organization is not a one-man show but has the collegial collective principle.

Besides the management is capable, the Founders and Trustees of The Indonesian Movement Helps as the state employees in Indonesia have the power to access various political and economic forces at home and abroad. For example, the book entitled "Lectures with IDR0.00" gets appreciation from national figures, it cannot be separated from the participation of the founders and trustees of The Indonesian Movement Helps. In addition to having a strong connection, the Founders and the Board of Trustees of The Indonesian Movement Helps also possess strong charismatic power. Therefore, they are able to maintain the spirit of the organizers of The Indonesian Movement Helps. "Saya membawa naskah buku "Kuliah dengan 0 Rupiah" ini ke bebrapa kolega di tanah air, sudah ada penerbit yang mendukung program ini. Saya pun bertemu beberapa tokoh nasional yang inspiratif agar bersedia untuk memberikan kata pengantar bagi buku ini agar anak-anak makin semangat. Alhamdulillah beberapa tokoh nasional seperti pak Ridwan Kamil bersedia memberikan kata sambutan untuk buku ini." (Agus Supriyadi, PNS Jawa Barat, PhD student of Nanjing Normal University, The Founder of The Indonesian Movement Help. Interview on August 2, 2019 - Nanjing City) Weaknesses: The points of Weaknesses for the Indonesian Movement Helps is that the organization slowly becomes short of members. Many activists of the organization have graduated from college and returned to Indonesia. On the other hand, The Indonesian Movement Helps has not found an equivalent substitute for those who have graduated. The shortage of activists and the slow pace of the organization in recruiting new activists have the potential to hamper the pace of the organization.

"Jadi ginimas, orangyang menjadi pengurus dari GIM (Gerakan Indonesia Membantu atau The Indonesian Movement Helps) beberapa sudah ada yang lulus, nggak gampang nyari penggantinya. Apa lagi anakanak Indonesia lainnya sudah ad yang aktif di kepengurusan PPI Tiongkok, KIRANA, dan lain-lain, jadi kita nyarinya yang kirakira masih punya banyak waktu luang." (Kukuh Pamuji, from Aceh, master student of 
Nanjing Normal University, The Chairman of The Indonesian Movement Help. Interview on August 2, 2019 - Nanjing City)

The person in charge has left each post, it must be filled. The potential person in charge should have a minimum ability equivalent to the forerunner. This cannot be ignored. Each division wheel in the organization relates to one another. If one wheel is stuck, it will affect the other wheels. Finally, another issue that The Indonesia Movement Helps should encounter is that the activists in the organization remain active students and they are already busy with their final assignments and others. Therefore, their performance becomes rather limited. As students, they are required to finish their education well.

"Kami tekankan juga pada anggota GIM (Gerakan Indonesia Membantu atau The Indonesian Movement Helps) kalau aktif di sini jangan sampai mengganggu aktifitas kuliah karena tujuan utama kalian datang kesini (Tiongkok) untuk belajar. Jadi kalau ada anggota yang tidak bisa aktif dalam suatu kegiatan GIM karena berbenaturan dengan agenda kuliuahnya kita juga memaklumi." (Dhona Putri, from East Java, master student of Nanjing Normal University, The Secretary of The Indonesian Movement Help. Interview on August 2, 2019 - Nanjing City)

Opportunity: The aforementioned weaknesses can be overcome if we consider existing opportunities. Over time more and more Indonesian citizens are studying in China. From the Chinese government scholarship at least two hundred Indonesian students are coming to China. It does not include the number of recipients of the Jasmine scholarships and the Confucius scholarships.

In early of the school year, the activists of The Indonesian Movement Helps can recruit potentials to fill out the abandoned posts. Moreover, the new students have not yet accomplished urgent lecture obligations such as the Final Projects in a kind of Essay, Thesis, and Dissertation. "Di setiap awal tahun ajaran PPI Tiongkok cabang Nanjing mengadakan acara Welcome Indonesia Freshman, semacam penyambutan bagiparamahasiswa baruasal
Indonesia di Tiongkok, dalam acara tersebut setiap perkumpulan pelajar Indonesia diberi kesempatan untikmemperkenalkan organisai masing-masing. Nah disitu GIM (Gerakan Indonesia Membantu atau The Indonesian Movement Helps) memperkenalkan diri sambal menawarkan pada mereka siapa yang mau bergabung dalam GIM." (Dhona Putri, from East Java, master student of Nanjing Normal University, The Secretary of The Indonesian Movement Help. Interview on August 2, 2019 - Nanjing City) There are new organizations in China such as the Islamic study groups of Husnul Khotimah and Amil Zakat Infak and Sadaqah Muhammadiyah Institutions (LAZIZMU). The existence of these organizations is able to collaborate well with The Indonesian Movement Helps. So far when the research was written, there were several joint work programs between The Indonesian Movement Helps and the aforementioned organizations.

Furthermore, Indonesian students in China gradually have had their own businesses. They have entrusted The Indonesian Movement Helps to allocate some of the profits from the business. It will be distributed to Indonesian students in China who are in need. Royalties from the book publication entitled "Lectures with IRD0.00" gradually make The Indonesian Movement Helps independent. So, it should not totally depend on the presence of donors in each work program of the organization.

Threats: The factors from outside the organization must pay in relation to the rules in China, particularly in Nanjing City. There should not be individuals with a double management position in organizations in China. So if an individual has already occupied a post in an organization, he or she will be not allowed to occupy a position in another organization. "Jadi gini mas, kayak yang tadi saya bilang, kadang ada anggota yang tidak bisa aktif karena sudah ada kesibukan di organisasi lain. Hal ini menjadi maslah juga bagi organisasi yang lain, jadi contohnya kayak PPI Tiongkok yang mengharuskan pengurusnya tidak menjabat di organisasi lain, hingga akhirnya bendahara kami ada 


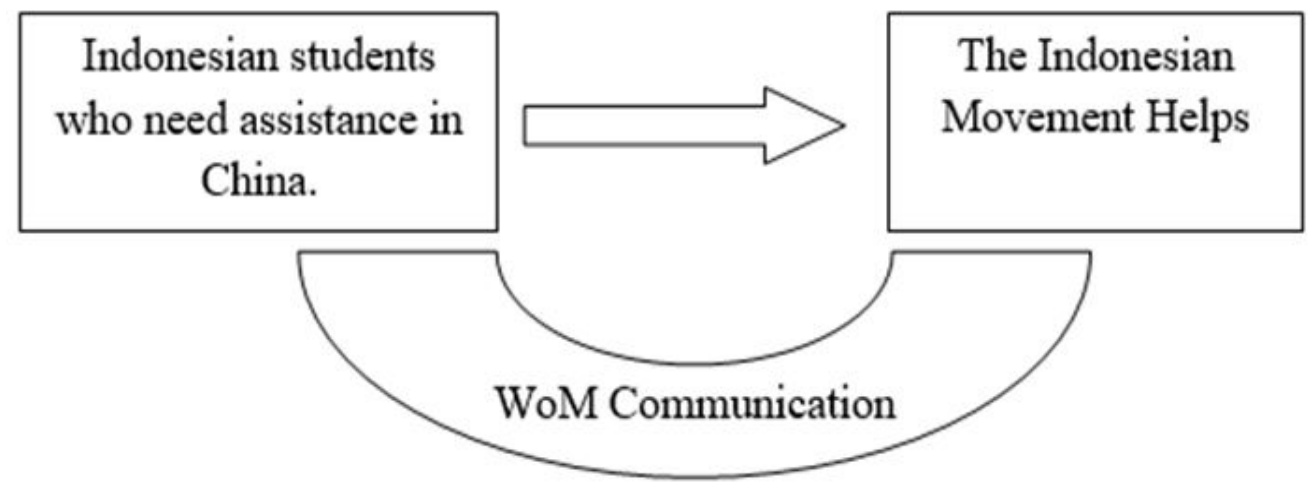

Figure 2. Communication Model of Indonesian Student Organizations in China through the Indonesian Movement Helps

Source: Author's analysis result (2020)

yang berhenti karena lebih memilih untuk aktif di PPI Tiongkok." (Kukuh Pamuji, from Aceh, master student of Nanjing Normal University, The Secretary of The Indonesian Movement Help. Interview on August 2, 2019 - Nanjing City) It potentially makes The Indonesian Movement Helps difficult to get new activists to occupy many posts in the organization management. It had ever occurred when The Indonesian Movement Helps had a new figure considered fit to occupy a post in the organization. However, the concerned activist had occupied a management position in the Indonesian Chinese Students Association. So the post having been prepared for the activist was vacant again. For The Indonesian Movement Helps, it has an opinion that it does not matter if there is an activist who occupies double posts in the management as long as the concerned activist has a commitment to the mandate that he or she has received. However, the rules related to this management remain a tradition in various organizations in China.

On the one hand, there are a number of Indonesian citizens who are supposed not to have understood correctly in relation to the actions of The Indonesian Movement Helps. Sometimes it gets destructive scorns. Phrases of that The Indonesian Movement Helps should "give a hook, not a fish" sometimes disrupt the positive energy of the activists of The Indonesian Movement Helps in running the wheels of the organization.
On the other hand, there is the concern of the activists of The Indonesian Movement Helps that the unscrupulous scholarship agents will exploit the existence of their organization. As confirmed about what kind of concern the unscrupulous scholarship agents will use, the Chairperson of The Indonesian Movement Helps replied that it was feared that the unscrupulous scholarship agents would say to potential Indonesian students who wanted to study in China that they should not worry about having a shortage of facilities while in China. The Indonesian Movement Helps was said to be ready to provide their help. Therefore, it is worried that the unscrupulous scholarship will carry the name of The Indonesian Movement Help while ensnaring their potential victims.

Actually, The Indonesian Movement Helps has created a system and so the unscrupulous scholarship agents cannot enter and take advantage of the organization. It aggressively carries out literacy and socialization and therefore, potential students do not easily believe what the unscrupulous scholarship agents have said. If so, they do not become the victims of fraud or they simply accept unclear information.

On the other hand, word of mouth (WoM) is an effective communication strategy to socialize the progress of the Indonesia Movement Helps in China (Figure 2). Indonesian students who get help from this organization always introduce the Indonesia Movement Helps when they meet other Indonesian students who also need assistance while in China. 


\section{Conclusion}

As an organization, The Indonesian Movement Help has a greater potential to develop than to be inhibited. It is shown that there are many Strengths and Opportunities if compared to Weaknesses and Threats. As it looks at this matter, it can be concluded that the things that potential factors to advance and smooth the performance of the organization from the internal and external of the organization are greater than those to impede the pace of the organization.

The decision-makers of the Indonesian Movement Helps should not waste the situation particularly the working climate in the internal of the organization built harmoniously. The positive organization culture must be maintained particularly for the organizations with the goal to serve the interests of the wider community like The Indonesian Movement Helps.

There are a number of factors that make the organization a little weaker. Firstly, some vacant posts in the management are sometimes left. They have to go home immediately to Indonesia or they are active in other organizations. Therefore, they could not perform in The Indonesian Movement Helps. Secondly, communication with Indonesian citizens in China must be strengthened. There are a great number of Indonesian citizens in China. Based on information the researcher has received from the board of the Indonesian Student Association, for the city of Nanjing alone as the basis of the Indonesian Movement Helps, total Indonesian students, amount to seven hundred people. These do not include others from their surroundings and other major cities in China.

In such circumstances, definitely, there are many people who are willing to take part in the Indonesian Movement Helps so that they can help their fellow Indonesian citizens who are in need of overseas bases. Therefore, the organizers of The Indonesian Movement Helps should carry out intensive communication and socialization actively. China is a country with a very high internet usage new media uses must be increased so that more and more people are moved to help their fellow Indonesian citizens in China in a kind of giving donations or joining the organization as its members. The mass media has the ability to influence human behavior and is capable of giving birth to a large movement.

Furthermore, the traditional approach of word of mouth must be maintained. This model of mouth-to-mouth communication has a very effective power to influence one's behavior. Indonesian people's literacy cannot be said to be high and therefore it is necessary to have a joint movement to make Indonesian people aware concerning the importance of receiving information as a whole so as not to become victims of the actions of irresponsible persons. The results of this study are expected to be a reference for other organizations similar to the subject of this study.

\section{Acknowledgements}

The authors thanks Ahmad Dahlan University andNanjing Normal University for supporting this research. The author also thanks to the Indonesian Movement Helps, who has been willing to provide data to the author during this research.

\section{References}

Abubakar, N., \& Bello, G. B. (2013). Strengths, Weaknesses, Opportunities and Threats (SWOT) Analysis on Globacom LTD. International Journal of Information Technology and Business Management, 16(1), 83-91. https:// www.jitbm.com/jitbm 16 volume/ Budiman, L. (2015). Komunikasi, Budaya Toleran dan Nasionalisme di Lingkungan Civitas Akademika UPN Veteran Yogyakarta. Jurnal Ilmu Komunikasi, 13(2), 145-157. Retrieved from http://jurnal.upnyk.ac.id/ index.php/komunikasi/article/view/1455

Fadillah, D. (2020). Belt Road Initiative in the Simulacra Analysis (Indonesia China Relationship in the Perspective of Indonesian Students in Nanjing City). 
Jurnal ASPIKOM, 5(1), 63-71. http:// dx.doi.org/10.24329/aspikom.v5i1.493 Fadillah, D., \& Kumajaya. (2017). Lompatan Strategis China Dalam Komunikasi Global. Samudra Biru. Fadillah, D., Nuryana, Z., \& -, S. (2020). Public Opinion of the facial recognition policy in China by Indonesian Student in Nanjing City. International Journal of Psychosocial Rehabilitation, 24(04), 1645-1652. https:// doi.org/10.37200/IJPR/V24I4/PR201272

Graita, D. I., \& Hastasari, C. (2018). Analisis Swot Strategi Komunikasi Internal Pegawai Pada Kantor Cabang BPJS Ketenagakerjaan Kota Yogyakarta. Student Journal of Communication, 1(1). Retrieved from $\mathrm{http}: / /$ journal.student. uny.ac.id/ojs/index.php/ilkom/index Gurel, E. (2017). SWOT Analysis: A Theoretical Review. The Journal of International Social Research, 10(51). https://doi.org/10.17719/jisr.2017.1832

Hatch, M. J. (2013). Organization Theory: Modern, Symbolic, and Postmodern Perspectives. Oxford University Press. Hatch, M. J., \& Cunliffe, A. L. (2006). Organizational Social Structure. In Organization Theory: Modern, Symbolic and Postmodern Perspectives. Manullang, L. A. (2009). Dasar Dasar Manajemen. Yogyakarta: Gadjah Mada University Press. Manullang, L. A. (2013). Teori Manajemen Komprehensif Integralistik Jakarta: Salemba Empat.

Mary J. H. A. L. C. (2018). Organiztion Theory. In Journal of Chemical Information and Modeling. https://doi. org/10.1017/CBO9781107415324.004 Maxwell, J. A., \& Reybold, L. E. (2015). Qualitative Research. In International Encyclopedia of the Social \& Behavioral
Sciences: Second Edition. https://doi. org/10.1016/B978-0-08-097086-8.10558-6

Nofrizal. (2018). Analisis SWOT untuk Menentukan Posisi Strategis Pada Universitas Lancang Kuning Pekanbaru. Human Falah, 5(2), 96-116. Retrieved from http://jurnal.uinsu.ac.id/index. $\mathrm{php/humanfalah/article/view/1621}$

Osita, I. C., R, I. O., \& Justina, N. (2014). Organization's stability and productivity: the role of SWOT analysis an acronym for strength, weakness, opportunities and threat. International Journal of Innovative and Applied Research, 2(9), 23-32. http://journalijiar.com/ uploads/2014-10-02_231409_710.pdf Phadermrod, B., Crowder, R., \& Wills, G. (2019). Importance-Performance Analysis based SWOT analysis. International Journal of Information Management, 44, 194-203. https://doi. org/10.1016/j.ijinfomgt.2016.03.009

Purnomo, E. P. (2010). Development of Local Institutions towards on Participation and Communication Model in the United Kingdom. Jurnal Ilmu Komunikasi, 8(3), 280-288. Retrieved from http://jurnal.upnyk. ac.id/index.php/komunikasi/article/view/132 Schooley, S. (2019). SWOT Analysis: What It Is and When to Use It. Business News Daily. https://www.businessnewsdaily. c o m / 4245 - s w o t - a na ly sis . h t m l Supratman, L. P. (2018). Pola Komunikasi Organisasi Kepemimpinan Strategis di PT TelkomSel. Jurnal Ilmu Komunikasi, 16(1), 31-41. http://jurnal.upnyk.ac.id/ index.php/komunikasi/article/view/2680

West, R., \& Turner, L. (2007). Introducing Communication Theory: Analysis and Application. McGraw-Hill. 